\title{
Confirmatory Strategic Information Technology Implementation for Building Information Modelling Adoption Model
}

\author{
*Wallace Imoudu Enegbuma', Godwin Uche Aliagha², \\ Kherun Nita Ali ${ }^{3}$ and Yusuf Yunusa Badiru ${ }^{3}$
}

Published online: 21 December 2016

To cite this article: Wallace Imoudu Enegbuma, Godwin Uche Aliagha, Kherun Nita Ali and Yusuf Yunusa Badiru. (2016). Confirmatory strategic information technology implementation for building information modelling adoption model. Journa of Construction in Developing Countries, 21 (2): 113-129. https://dx.doi.org/10.21315/jcdc2016.21.2.6.

To link to this article: https://dx.doi.org/10.21315/jcdc2016.21.2.6

Abstract: Information technology (IT) developments in the construction industry require a proportionate response by construction professionals. Building information modelling (BIM) requires strategic changes to the traditional ways construction is carried out. BIM adoption in Malaysia is growing because of recent efforts to sensitise construction professionals on the need for strategic IT implementation. This paper builds on the theory of business process reengineering and computer integrated construction for a BIM adoption model. Data were collected from 352 construction professionals (architects, quantity surveyors, engineers and contractors). The data were analysed using Statistical Package for Social Sciences (SPSS) version 18 for descriptive modelling and Analysis of Moment of Structures (AMOS) version 18 for structural equation modelling. Descriptive results showed a high prevalence of the need for BIM competent professionals. Multivariate results revealed a high correlation within the measurement model for business process re-engineering and computer integrated construction. The second-order confirmatory model showed that business process reengineering and computer integrated construction had a high impact on strategic IT Implementation. Overall, the model validated the conceptual framework of the impact of strategic IT implementation on the adoption rate of BIM in the perception of construction industry professionals in Malaysia. The result denotes the first part of the full adoption model, which can be compared with the adoption rate in other countries. Subsequent research using a diverse sample selection focuses on the mediating effect of collaboration on BIM adoption.

Keywords: Adoption, Building information modelling (BIM), Construction, Information technology (IT), Malaysia

\section{INTRODUCTION}

Building information modelling (BIM) presents ample advantages for construction professionals that invariably lead to improvements in efficiency and client satisfaction. Smith and Edgar (2008) and McCuen and Suermann (2007) defined BIM as a digital representation of physical and functional characteristics of a facility that serves as a shared knowledge resource that forms a reliable basis for decisions during its life cycle, from inception onward. A basic premise of BIM is the

'Faculty of Engineering, Computing and Science, Swinburne University of Technology Sarawak, Kuching, Sarawak, MALAYSIA

2Faculty of Geoinformation and Real Estate, Universiti Teknologi Malaysia, Skudai, Johor Darul Takzim, MALAYSIA

${ }^{3}$ Faculty of Built Environment, Universiti Teknologi Malaysia, Skudai, Johor Darul Takzim, MALAYSIA

*Corresponding author: wenegbuma@swinburne.edu.my

(c) Penerbit Universiti Sains Malaysia, 2016 
collaboration of different stakeholders at different phases of a facility's life cycle to insert, extract, update or modify information in the model to support and reflect the roles of that stakeholder. The model is founded on open standards for interoperability. BuildingSMART (2010) was of the opinion that "BIM is a new approach to being able to describe and display the information required for the design, construction and operation of constructed facilities. It can bring together the different threads of information used in construction into a single operating environment, thus reducing, and often eliminating, the need for the many different types of paper documents currently in use".

\section{BUILDING INFORMATION MODELLING ADOPTION}

The Malaysian construction industry has experienced tremendous growth since the implementation of the Vision 2020. Current information and communication technology (ICT) policies under the 10th Malaysian Economic Plan have given a further boost to the construction industry. BIM implementation policies are in the formulation stages, although Mohd-Nor, Usman and Mazlan-Tahir (2009) highlighted the low knowledge levels of complex information technology (IT) tools that resist rapid BIM adoption. In tertiary training, frameworks have been developed to help improve BIM skillset training for future quantity surveying graduates in Malaysia, with recommendations for increased awareness and initiation of proficiency training among personnel (Ali et al., 2015). The uncertainty of legal liability for professionals involved in a BIM model also presents a hurdle (Rosenberg, 2006), requiring legal maturity and improvement in contract management (Rezqui and Zarli, 2006; Liu, 2010). The Standards and Industrial Research Institute of Malaysia (SIRIM) formulated a strategic IT plan to improve productivity within the construction industry under the auspices of the Economic Planning Unit (EPU) (EPU, 2009; SIRIM, 2009; Haron, 2013). Through a mixed methods approach, Chong, Preece and Rogers (2014) developed a conceptual framework that forecasts future BIM development, tending towards new government initiatives and regulation. Irrespective of all the perceived policies, the implementation of ICT by construction professionals remains at disproportionate levels (Ali, Al-Jamalullail and Boon, 2013; Haron, 2013; Enegbuma et al., 2014). Internet usage was found to increase efficiency and cost savings among Malaysian construction firms, with construction professionals spending productivity time on the internet for email and information search; with BIM, such time could be channelled to model updates and collaboration (Mui et al., 2002; Haron, 2013). Similarly, research on ICT implementation in Malaysian construction firms was also slow in coming (Jaafar et al., 2007; Haron, 2013). Among engineering consulting services firms, poorly trained personnel, insufficient adoption guidance and inadequate government support were found to affect BIM adoption adversely (Rogers, Chong and Preece, 2015). Strategic implementation is inadequate in the Malaysian construction industry, which invariably limits the proper implementation of building information modelling (Haron, 2013). This improper strategic outlook, in the long run, leads to failure in implementation, as most ICT implementations result from peer pressure (Li, Irani and Love, 2000; Mui et al., 2002; Haron, 2013). Among contractors, the cost of software was a barrier to adoption, along with staff resistance and inadequate knowledge. Consultants were of the opinion that cost

114/PENERBIT UNIVERSITI SAINS MALAYSIA 
and system stability are hindrances. Government agencies were sceptical about the compatibility and interoperability, while academics remained worried about the low pool of BIM experts in the industry (Harris et al., 2014). Adoption of BIM upgrades a firm's competitive differentiation strategy, ensuring survival and increases in productivity (Abidin, Adros and Hassan, 2014).

The first government project to fully utilise BIM was launched in 2010 to build the National Cancer Institute (NCI) in Sepang (Ismail, 2014). In 2013, the National BIM Steering Committee was established by Construction Industry Development Board (CIDB), assisted by seven sub-committees, namely, standards and accreditation, incentives, education and awareness (academia), National BIM component library, BIM guidelines, BIM special interest group and research and development (Ismail, 2014; CIDB, 2014; Enegbuma et al., 2014). In 2014, the Malaysian Chapter of BuildingSMART international was officially registered in support of open BIM platforms and a policy push for BIM (Ismail, 2014). This awareness drive allowed the government to provide a positive leadership towards collaboration and improvement in BIM adoption (Vroom and Jago, 2007; Ofori and Toor, 2012).

This paper aims to assess the connections between business process changes experienced in the construction industry. The drive for better computer integrated construction and the theoretical position of collaboration in the construction industry are also evaluated. To achieve this aim, previous literature was examined to identify the factors affecting BIM adoption, the perception of construction professionals and the significance of the relationship between these factors. The following section addresses the hypotheses. Later, the methodology, results and discussion are presented and the implications of the research examined.

\section{BUSINESS PROCESS RE-ENGINEERING}

Betts (1999) opined that business process redesign, process innovation and business process re-engineering (BRP) form an integral part of the same theories that are separated in terms of nomenclature. IT plays a vital role in BPR and thus several researchers have argued that expenditures on IT will yield benefits of productivity increments, improved efficiency and effectiveness if there is a focus shift to a critical analysis of the technology's use. To avoid the pitfalls of implementing new IT over old processes, new processes to match IT, such as organisational structure, procedures, practices and tasks, should be adopted (Drucker, 1988; Schnitt, 1993; Liang and Cohen, 1994). The modus operandi of the construction industry is forced to transform and improve to meet the growing pressure from external political, economic and other considerations (Amor and Anumba, 1999). Integrating IT systems with business processes reshapes and facilitates the organisational culture, performed task and coordinated activities (Davenport and Short, 1990; Hinterhuber, 1995; Hammer, 1990; Willcocks and Smith, 1994; Tapscott and Caston, 1993; Klenke, 1994; Alter, 1993; Davenport, 1993; Alshawi, 2007; Enegbuma and Ali, 2012; 2013; Enegbuma, Aliagha and Ali, 2013). The cultural change of modifying the traditional standard process presents great challenges (Sánchez and Valencia, 2011), such that only a select number of professionals utilise the BIM model (Iguarán, 2010). This demonstrates an adamant 
resistance to change in favour of new systems in the construction industry. The phenomenon known as "people managers" shows the importance of people's influence on how organisations adapt to new IT technologies. Hence, understanding ways to tap into individual creative energy, intelligence and initiative, manage change and allay fears of change is critical to implementation success (Towers, 1996, Cooper and Markus, 1995; Kennedy, 1994; Arendt, Landis and Meister, 1995; Alshawi, 2007).

Several conflicts and apprehensions arose during BIM usage in Hong Kong. Among the issues observed were the need for smooth BIM interoperability among the model's participants. Although BIM is accepted both as a new tool and a new process, changes for people, processes, communication and work culture is unavoidable. Other conflicts include computability of the design data, information exchange and clashes among the BIM components and technical barriers such as a poor library, low running speed of the system and lack of table customisation. Additionally, early contractor input is still lacking in Hong Kong, with most design work performed independently by architects or engineers. At the industry level, innovative technology such as BIM requires more efforts and time to implement and thus faces resistance from current project processes and the prevalent fast track culture. Therefore, business process re-engineering in the industry has an effect on BIM adoption, leading to the hypothesis that:

$\mathrm{H1}$ : There is a significant relationship between business process re-engineering (BPR) and BIM Adoption (BA).

\section{COMPUTER INTEGRATED CONSTRUCTION}

The concept of integrated computer environment research has been a subject of interest since the early 1990's. Technology uptake has seemed slow because of the rapid development of IT systems and their inadequate implementation by the construction industry. Researchers and industrialists attempted to utilise IT as an enabling technology to reduce the problems of communication and information sharing within the construction industry (Alshawi and Faraj, 2002; Aouad and Wafai, 2002; Sarshar, Christiansson and Winter, 2004; Arayici, Ahmed and Aouad, 2005; Enegbuma and Ali, 2013). Someya (1992) proposed that, gradually, computer integrated construction $(\mathrm{ClC})$ overcomes the challenges of immaturity in computer technology of hardware and software. This is aimed at improving effective and quick customer design and technological capability, integration of production and information, shorter development cycle for efficiency and strategic management to react to a changing external environment. Similarly, Clifton and Sunder (1997) opined that $\mathrm{CIC}$ helps the industry share, exchange and manage knowledge through a neutral knowledge interchange format. Björk (1999) further fuelled the growing trend in information technology in construction (ITC) by stressing the need to define the discipline in research through determining domains and boundaries, analysing the actual effects of IT in the overall construction process and testing tools beneficial to potential process reengineering. Koskela and Salagnac (1990) in comparing CIC development across France, Finland, Japan and US found that the perceived transformation need, the 
scale of the output of the construction industry, the degree of anticipatory action in the construction industry and overall research and development (R\&D) in construction are determinants in developing computer integrated construction. Clifton and Sunder (1997) supported the infusion of $\mathrm{CIC}$ in the reports of the National Institute of Standards and Technology for computer integrated knowledge system (CIKS) to cater for construction material, components and systems. Goh and Chu (2002) highlighted the positive launch of the national code of practice, SS CP80:1999, by the Construction Industry IT Standards Technical Committee (CITC) in Singapore after its establishment in 1998. CITC was tasked with establishing an industry-wide framework for the development and adoption of IT standards in construction, including the effective facilitation of $\mathrm{CIC}$ and information standardisation in Singapore. To accomplish this task, cultural change and adjustment in the standards of practice were necessary, including a mental shift from the inherent dependence on government-driven initiatives and the cost of change to be borne by the government. The code was developed through a blend of international standards and adaptations to local industry practice. Thus, $\mathrm{CIC}$ presents the effects of BIM adoption and correlates to the previously mentioned construct of business process change in the industry, leading to the hypotheses that:

H2: There is a significant relation between computer integrated construction $(\mathrm{CIC})$ and BIM adoption (BA).

H2a: Business process re-engineering (BPR) and computer integrated construction $(\mathrm{ClC})$ are correlated.

\section{COLLABORATIVE PROCESSES}

Jayasena and Weddikkara (2013) emphasised the need for collaborative processes in the construction industry, which they posited helps in assessing BIM maturity. "Collaboration can further be seen as working together in a seamless team for common objectives that deliver benefit to all. Collaboration is more effective when undertaken at the project inception stage" (Anumba and Newnham, 2000). Yeomans, Bouchlaghem and El-Hamalawi (2006) also argued that there is no disadvantage to adopting collaborative practices in the construction industry. The driving force of collaboration is dependent on the commitment of the project team, the merging of collaborative ideals with procurement systems and the development of a means to capture and report the benefits. Sommerville and Craig (2006) argued that the increased usage of IT in business processes results from the increased awareness of the benefits of open, collaborative efforts by project teams in the construction industry. The push for effective collaboration will inadvertently provide higher productivity and returns on investments for clients' increased demands. Arayici et al. (2011) and Arayici, Egbu and Coates (2012) argued that active collaboration and learning by carrying out practical tasks during BIM implementation improve BIM adoption by practitioners and researchers. This approach was utilised under the auspices of a knowledge transfer partnership (KTP) in John McCall Architects (JMA). Yeomans, Bouchlaghem and El-Hamalawi (2006) expressed the need for certain project 
teams to provide extra effort towards achieving collaboration. However, in Malaysia, current literature is inconclusive as to which project team members should engage more in a push towards effective collaboration. The apprehension of distrust and litigation processes often leads to ineffective collaboration. The noncollaborative nature of the construction industry is fuelled by the rampant silo working mode, where all intelligent coordination and agility advantages gained in a collaborative environment are corrupted or lost (Owen et al., 2010; Jayasena and Weddikkara, 2013; Enegbuma et al., 2014). Thus, collaborative processes serve to mediate between business process re-engineering and computer integrated construction to improve BIM adoption. We hypothesise that:

H3: There is a significant relationship between collaborative processes and BIM adoption (BA).

$\mathrm{H} 4$ : There is a significant relationship between the collaborative process and business process re-engineering (BPR).

H5: There is a significant relationship between collaborative processes and computer integrated construction $(\mathrm{ClC})$.

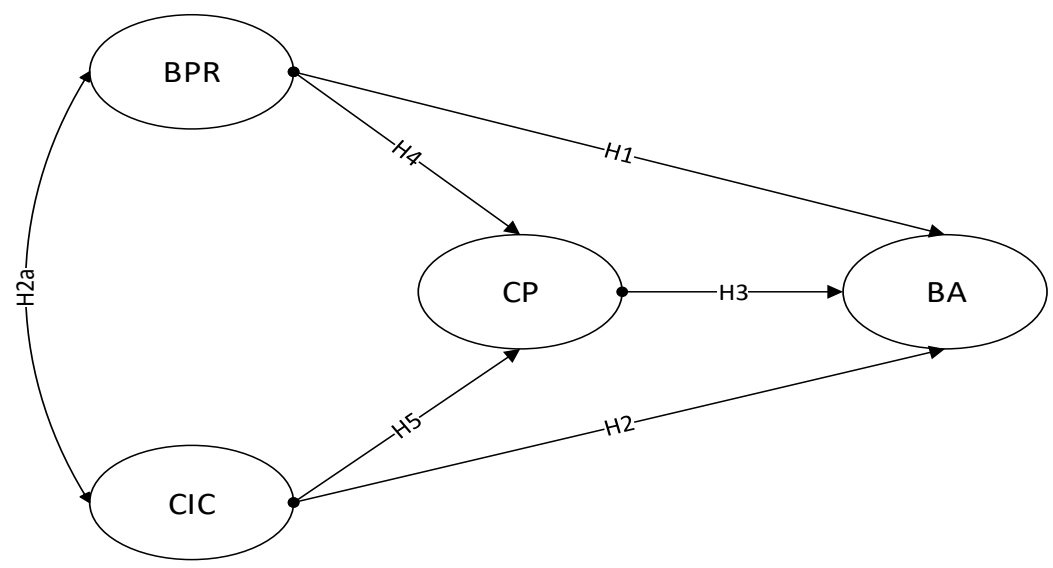

Figure 1. Hypothesised Model

\section{METHODOLOGY}

From a quantitative approach, the research epistemology is driven by the positivist view. This targets examining and deriving an explanation for BIM adoption in the Malaysian construction industry. To derive the relationship between the variables of this paper, alternate hypotheses were stated in opposition to the null hypotheses (Creswell, 2008). Appropriate representation within the population requires an adequate sample frame, selection and size (Fowler, 1993; Paschke, 2009). A random sampling frame to collect data from a subset forming a representative data for the group was used (De-Vaus, 2002). Sample frames from previous research in IT and BIM were studied, and a frame was developed 
covering medium to large construction organisations in addition to CIDB Class-A contractors (Son et al., 2012; Lowry, 2002; Peansupap and Walker, 2005; Davis and Songer, 2008; Jacobsson and Linderoth, 2012; Peansupap and Walker, 2006; Miller, Radcliffe and Isokangas, 2009; Brewer and Gajendram, 2011; Samuelson, 2011; Davies and Harty, 2013; Son et al., 2014; XU, Feng and Li, 2014). The previously mentioned studies possessed an average sample size of 255 respondents and Hair et al. (2010) specified a minimum sample size of 200 for structural equation modelling (SEM). The primary respondents were construction professionals (architects, quantity surveyors, engineers and contractors) possessing knowledge on challenges faced in BIM adoption. Three hundred fifty-two responses were screened following the steps for structural equation modelling (SEM) outlined by Hair et al. (2006, 2010). A total of 292 were usable, falling within the minimum threshold for SEM multivariate analysis (Hair et al., 2006; 2010; Awang, 2012). The research instrument contained four sections measuring BPR, CIC, CP and BA with items listed in Table 1.

Table 1. Items Measuring Constructs

\begin{tabular}{|c|c|}
\hline Items & Description \\
\hline BPR1 & Malaysian construction industry is changing its business process to suit BIM \\
\hline BPR2 & $\begin{array}{l}\text { Malaysian construction industry provides support for building information } \\
\text { modelling training }\end{array}$ \\
\hline BPR3 & $\begin{array}{l}\text { Malaysian construction industry policy encourages recruitment of personnel } \\
\text { proficient in building information modelling }\end{array}$ \\
\hline BPR4 & $\begin{array}{l}\text { Malaysian construction industry provides adequate research and } \\
\text { development into IT }\end{array}$ \\
\hline BPR5 & $\begin{array}{l}\text { Malaysian construction Industry has a clear implementation framework for } \\
\text { building information modelling }\end{array}$ \\
\hline $\mathrm{ClCl}$ & I feel IT drives for full automation in the construction industry \\
\hline $\mathrm{ClC} 2$ & I feel more research into IT integration in construction should be encouraged \\
\hline $\mathrm{ClC} 3$ & I feel construction industry has adapted quickly to IT improvements \\
\hline $\mathrm{ClC} 4$ & $\begin{array}{l}\text { I feel a division of project teams affects IT usage and development in } \\
\text { construction }\end{array}$ \\
\hline $\mathrm{ClC} 5$ & I feel BIM provides an intelligent IT solution to the construction industry \\
\hline $\mathrm{ClC} 6$ & I feel IT usage is dependent on the project size \\
\hline CP1 & I feel current communication is adequate for collaboration \\
\hline CP2 & I feel current standard forms of contract encourage collaboration \\
\hline CP3 & $\begin{array}{l}\text { I am comfortable with the current stage of work where collaboration is } \\
\text { introduced }\end{array}$ \\
\hline CP4 & I feel collaboration aligns the project objectives and teams \\
\hline CP5 & $\begin{array}{l}\text { I feel there are sufficient building information modelling collaboration protocol } \\
\text { documents in the industry }\end{array}$ \\
\hline $\mathrm{BA} 1$ & $\begin{array}{l}\text { Building information modelling will expose me to new ways of reasoning for } \\
\text { projects }\end{array}$ \\
\hline
\end{tabular}

(Continued on next page) 
Wallace Imoudu Enegbuma et al.

Table 1. (Continued)

\begin{tabular}{ll}
\hline BA2 & I will be comfortable with collaboration with project teams \\
BA3 & Greater communication will be achieved among project team members \\
BA4 & $\begin{array}{l}\text { Building information modelling draws the construction industry closer to the set } \\
\text { Construction Industry Master Plan (CIMP) }\end{array}$ \\
BA5 & Cost savings will be achieved through building information modelling \\
BA6 & Overall client satisfaction will be achieved with building information modelling \\
\hline
\end{tabular}

The measures of reliability for all items were carried out before the test for content and discriminant validity. The measurement model was tested to meet the required model indices, and, subsequently, the structural model was assessed.

\section{RESULTS AND DISCUSSION}

The demographic results in Table 2 showed that the categories of respondents were architects (37.3\%), quantity surveyors (17.8\%), engineers $(32.5 \%)$ and contractors (12.3\%). The major age bracket fell within $25-35$ years $(55.1 \%)$. The private sector accounted for $65.5 \%$ of the construction professionals. A total of $52.6 \%$ held a position of junior management in their respective firms and $59.4 \%$ possessed a bachelor degree. Regarding work experience, $54.6 \%$ of the professionals had a minimum of 6-10 years of working experience in the construction industry and subsequently registered with various professional affiliations, whereas $45.1 \%$ expressed the opinion that they were beginning users of BIM.

Table 2. Demographics of Respondents

\begin{tabular}{llcc}
\hline Characteristics & Categories & N & \% \\
\hline Designation & Architect & 109 & 37.3 \\
& Quantity surveyor & 52 & 17.8 \\
& Engineer & 95 & 32.5 \\
Gender & Contractor & 36 & 12.3 \\
& Male & 225 & 77.1 \\
Age bracket & Female & 60 & 20.5 \\
& Below 25 years & 23 & 8.7 \\
& 25-35 years & 146 & 55.1 \\
& 35-45 years & 95 & 35.8 \\
Construction sector & Above 45 years & 1 & 0.4 \\
& Public sector & 96 & 34.5 \\
\hline
\end{tabular}

(Continued on next page)

120/PENERBIT UNIVERSITI SAINS MALAYSIA 
Table 2. (Continued)

\begin{tabular}{llcc}
\hline Position in establishment & Executive & 25 & 9.2 \\
& Senior management & 104 & 38.2 \\
& Junior management & 143 & 52.6 \\
Years of experience & $1-5$ years & 113 & 40.4 \\
& $6-10$ years & 153 & 54.6 \\
& $11-15$ years & 13 & 4.6 \\
Level of BIM involvement & $16-20$ years & 1 & 0.4 \\
& Beginner & 129 & 45.1 \\
& Novice & 127 & 44.4 \\
& Intermediate & 27 & 9.4 \\
& Advanced & 2 & 0.7 \\
& Expert & 1 & 0.3 \\
\hline
\end{tabular}

With the adoption of BIM, the industry continues to see an upward shift in the adoption of BIM. Architects more often use Autodesk Revit for design purposes, whereas the BIM collaborative element still needs improvement in line with other construction professionals. The lower age bracket of professionals predominant in this study highlights an increasing rate of skill acquisition favouring BIM. However, experience in the industry plays a vital role in policy formation and drive to collaborate in practice. The private sector push for BIM within the sample highlights the need for a competitive advantage in project bid and execution. This will result in the long run complement the recent involvement of the government sector.

The Instrument pools generated for all the constructs were measured for internal consistency, and all constructs were above the threshold of $>0.60$. Items that failed to meet the criteria were screened at the instrument cleaning stage. In the one-factor congeneric model, all constructs showed discriminant validity and convergent validity (Hair et al., 2010). The measurement model was examined using the covariance of all constructs, and a prelude to the attributes of the structural model showed that all fit indices were within the acceptable thresholds, as shown in Table 3.

Table 3. Goodness-of-fit Indices for Measurement Model

\begin{tabular}{ccc}
\hline Fit Index & Acceptable Fit & Indices for Data \\
\hline$X^{2}$ & & 234.08 \\
$\mathrm{df}$ & & 97 \\
$\mathrm{P}$ & $<0.05$ & 0.00 \\
$X^{2} / \mathrm{df}$ & $\leq 2-5$ & 2.41 \\
Root Mean Square Residual (RMR) & $<0.06$ & 0.03 \\
Comparative Fit Index (CFI) & $\geq 0.90$ & 0.90 \\
Goodness of Fit Index (GFI) & $\geq 0.90$ & 0.91 \\
Root Mean Square Error of & $\leq 0.05-0.80$ & 0.70 \\
Approximation (RMSEA) & & \\
\hline
\end{tabular}


The next step after the measurement model examination for fit indices was the assessment of the structural model. The major aim was to examine the validity of the relationship within the structural model. The hypotheses of the structural model were exhibited previously in Figure 1 to indicate the direction of impact and relationships among all constructs. The examination of the goodness of fit indices in Figure 2 indicated a model fit in accordance with the data from respondents and aligned with BIM theory. The indices showed that $X^{2} / d f$ is 2.4 , which fell in the acceptable threshold of between 2 and 5 (Hair et al., 2010). The Comparative Fit Index (CFI) and Goodness of Fit Index (GFI) are 0.90 and 0.91 , respectively, which also fell within the acceptable thresholds (Hair et al., 2010).

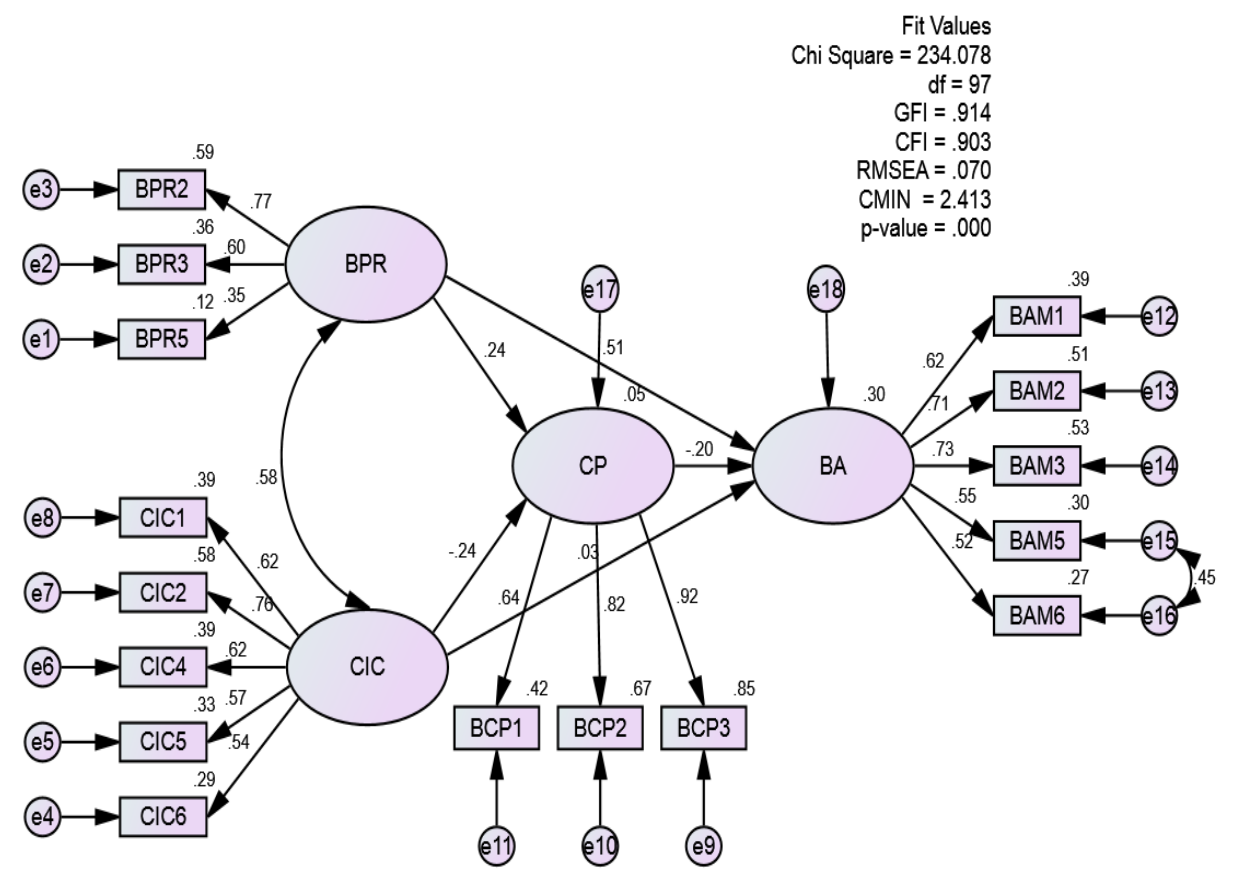

Figure 2. Structural Model

The next step assesses the strength of the relationships to denote the overriding hypothetical standpoint on this research. The path coefficient is determined by the regression weights shown in Table 4. Constructs with critical ratios (C.R.) above 1.96 are considered to be statistically significant in the model (Hair et al., 2010). Of the five hypotheses generated, four were statistically significant, but one construct, the impact of computer integrated construction on BIM adoption, was found to be statistically insignificant in this model. The results suggest that construction professionals currently feel overburdened by the need to upgrade IT systems in their daily work practice. Although IT promises to automate and implement other improvements for a more efficient construction process, the reactions by the construction professionals to match the rapid development in BIM calls for more proactive hands-on experience. 
Table 4. Structural Model Estimates and Hypothesis Testing

\begin{tabular}{|c|c|c|c|c|c|c|c|c|}
\hline & & & Estimate & S.E. & C.R. & $\mathbf{P}$ & Label & Hypotheses \\
\hline $\mathrm{CP}$ & $\leftarrow$ & BPR & 0.715 & 0.341 & 2.094 & 0.036 & par_15 & Significant \\
\hline $\mathrm{CP}$ & $\leftarrow$ & $\mathrm{ClC}$ & -0.435 & 0.188 & -2.314 & 0.021 & par_16 & Significant \\
\hline BA & $\leftarrow$ & BPR & 0.677 & 0.199 & 3.410 & $* * *$ & par_14 & Significant \\
\hline BA & $\leftarrow$ & $\mathrm{CIC}$ & 0.026 & 0.085 & 0.302 & 0.763 & par_17 & Insignificant \\
\hline BA & $\leftarrow$ & $C P$ & -0.086 & 0.031 & -2.740 & 0.006 & par_19 & Significant \\
\hline
\end{tabular}

Previous research posited that business process re-engineering has an effect on BIM adoption (Alshawi, 2007; Betts, 1999; Davenport and Short, 1990; Hinterhuber, 1995; Hammer, 1990; Willcocks and Smith, 1994; Tapscott and Caston, 1993; Klenke, 1994; Alter, 1990; Davenport, 1993), and this was confirmed by the findings of this research. This suggests that the construction professionals in Malaysia perceive the current process change in the industry; the alignment will invariably lead to improved BIM adoption. This construct exhibited a strong direct impact on BIM adoption (51\%).

The correlation of the two constructs argued by this research linked business process re-engineering and computer integrated construction, which was confirmed by a strong value (0.58). This implies that the future alignment of business process re-engineering and computer integrated construction will continually improve BIM adoption, as hypothesised by the authors. Contrary to previous research (Alshawi and Faraj, 2002; Aouad and Wafai, 2002; Sarshar, Christiansson and Winter, 2004; Arayici, Ahmed and Aouad, 2005; Someya, 1992), computer integrated construction exhibited a statistically insignificant effect in this study. This suggests that the construction professionals have yet to align with this perception. The collaborative process was found to have a statistically significant effect on BIM adoption, which was in line with previous research (Jayasena and Weddikkara, 2013; Arayici et al., 2011; Arayici, Egbu and Coates, 2012; Yeomans, Bouchlaghem and El-Hamalawi, 2006; Owen et al., 2010). However, business process re-engineering and computer integrated construction both had a statistically significant effect on collaborative processes. This fortifies the initial hypotheses arguing for the need to examine these constructs as mediated by collaborative processes in the construction industry. Overall, the variance extracted (0.30) accounted for the explanation of the features of BIM adoption in Malaysia, while collaborative process (0.05) portrayed a significantly low figure that will increase with the industry's drive towards improved collaboration among construction professionals.

\section{CONCLUSION}

This paper sets out to examine the relationships between several constructs affecting BIM adoption in Malaysia. This was achieved through an assessment of the SEM model fit indices and strength of relationship between the constructs. The argument for the correlation and mediation of constructs derived from past research informed the model formation that assesses BIM adoption. The goodness 
of fit of the structural model preceded by the measurement model further strengthened the hypotheses developed. Four statistically significant relationships were established. From the findings, it is recommended to improve grey areas such as the standard forms of contract to improve collaboration in the construction industry among construction professionals. Addendum and clauses that improve and encourage collaboration should be added, as observed in other, more mature BIM construction industries. Continual formulation of policies favourable to BIM is encouraged. The model can be utilised for future research in assessing the perceptions of other key stakeholders in the construction industry.

\section{REFERENCES}

Abidin, N.Z., Adros, N.A. and Hassan, H. (2014). Competitive strategy and performance of quantity surveying firms in Malaysia. Journal of Construction in Developing Countries, 19(2): 15-32.

Ali, K.N., Al-Jamalullail, S.N.N.I. and Boon, T.C. (2013). Building Information Modeling Awareness and Readiness: Among Quantity Surveyors and Quantity Surveying Firms. Selangor, Malaysia: Royal Institution of Surveyors Malaysia (RISM).

Ali, K.N., Mustaffa, N.E., Keat, Q.J. and Enegbuma, W.I. (2015). Building information modelling (BIM) educational framework for quantity surveying students: The Malaysian perspective. Proceedings: The 9th BIM Academic Symposium and Job Task Analysis Review. Washington DC, 7-8 April.

Alshawi, M. (2007). Rethinking IT in Construction and Engineering: Organisational Readiness. London and New York: Taylor and Francis.

Alshawi, M. and Faraj, I. (2002). Integrated construction environments: Technology and implementation. Construction Innovation, 2(1): 33-51. http://dx.doi.org/10.1108/14714170210814676.

Alter, A. (1990). The corporate make-over. Chief Information Officers (ClO), 4(3): 32-42.

Amor, R. and Anumba, C.J. (1999). A survey and analysis of integrated project databases. Proceedings: Concurrent Engineering in Construction. Espoo, Finland: VTT Technical Research Centre of Finland.

Anumba, C.J. and Newnham, L.N. (2000). Computer-based collaborative building design: Conceptual model. International Journal of Construction Information Technology, 8(1): 1-14.

Aouad, G. and Wafai, M.H. (2002). Implementation of information technology in the construction industry: The conceptual methodology approach. Paper presented at the 2nd International Postgraduate Research Conference in the Built and Human Environment. University of Salford, Salford, 11-12 April.

Arayici, Y., Ahmed, V. and Aouad, G. (2005). A requirements engineering framework for integrated systems development for the construction industry. ITcon, 11:35.

Arayici, Y., Coates, P., Koskela, L.J., Kagioglou, M., Usher, C. and O'Reilly, K. (2011). BIM adoption and implementation for architectural practices. Structural Survey, 29(1): 7-25. https://doi.org/10.1108/02630801111118377.

124/PENERBIT UNIVERSITI SAINS MALAYSIA 
Arayici, Y., Egbu, C. and Coates, P. (2012). Building information modelling (BIM) Implementation and remote construction projects: Issues, challenges, and critiques. Journal of Information Technology in Construction (ITcon), 17: 7592.

Arendt, C., Landis, R. and Meister, T. (1995). The Human Side of Change: Part 4. Georgia, USA: IIE Solutions, 22-27.

Awang, Z. (2012). A Handbook on SEM Structural Equation Modeling: SEM Using AMOS Graphic. 5th Ed. Kelantan, Malaysia: Universiti Teknologi Mara Kelantan.

Betts, M. (1999). Strategic Management of IT in Construction. Oxford: Blackwell Science Ltd.

Björk, B. (1999). Information technology in construction domain definition and research issues. International Journal of Computer Integrated Design and Construction, 1(1): 1-16.

Brewer, G. and Gajendram, T. (2011). Attitudinal, behavioural, and cultural impacts on e-business use in a project team: A case study. Journal of Information Technology in Construction, 16: 637-652.

BuildingSMART. (2010). Terms and Definitions. Available at: http://www. buildingsmart.org.hk/index.php/terms-and-definitions/ [Accessed on 12 August 2010].

Chong, H.Y., Preece, C. and Rogers, J. (2014). BIM update 2013: A mixed review approach from academia and industry. Trends and Development in Management Studies, 3(1): 1-21.

Clifton, J.R. and Sunder, S.S. (1997). A partnership for a national computerintegrated knowledge systems network for high-performance construction materials and systems: Workshop report. National Institute of Standards and Technology Report 6003. Gaithersburg, MD: National Institute of Standard and Technology.

Construction Industry Development Board (CIDB) Malaysia. (2014). Building information modelling (BIM) roadmap for Malaysia's construction industry (2014-2020). Construction Industry Development Board Workshop Report (Series 2). Kuala Lumpur: CIDB Malaysia.

Cooper, R. and Markus, M. (1995). Human engineering. Sloan Management Review, 36(4): 39-50.

Creswell, J.W. (2008). Educational Research: Planning, Conducting, and Evaluating Quantitative and Qualitative Research. 3rd Ed. Upper Saddle River, NJ: Pearson.

Davenport, T. (1993). Process Innovation: Re-Engineering Work through Information Technology. Boston, MA: Harvard Business School Press.

Davenport, T.H. and Short, J.E. (1990). The new industrial engineering: Information technology and business process redesign. Sloan Management Review, 13(14): 11-27.

Davies, R. and Harty, C. (2013). Measurement and exploration of individual beliefs about the consequences of building information modelling use. Construction Management and Economics, 31(11): 1110-1127. https://doi.org/10.1080/01446193.2013.848994.

Davis, K.A. and Songer, A.D. (2008). Resistance to IT change in the AEC industry: An individual assessment tool. Journal of Information Technology in Construction, 13: 56-68. 
De-Vaus, D.A. (2001). Research Design in Social Research. London: Sage Publications.

Drucker, P. (1988). The coming of the new organisation. The Harvard Business Review, January-February: 45-53.

Economic Planning Unit. (2009). Ninth Malaysia Plan 2006-2010. Putrajaya, Malaysia: Economic Planning Unit, Prime Minister's Department.

Enegbuma, W.I. and Ali, K.N. (2013). Hypothesis analysis of building information modelling penetration in Malaysian construction industry. Proceedings of the CIB World Building Congress 2013. Brisbane: Queensland University of Technology.

Enegbuma, W.I. and Ali, K.N. (2012). A theoretical framework for building information modelling penetration in Malaysian construction industry. Proceedings: Management in Construction Research Association (MiCRA) Post Graduate Conference. Kuala Lumpur: RAZAK School of Engineering and Advanced Technology, Universiti Teknologi Malaysia.

Enegbuma, W.I., Aliagha, U.G. and Ali, K.N. (2013). Preliminary building information modelling adoption model in Malaysia: A strategic information technology perspective. Construction Innovation, 14(4): 408-432.

Enegbuma, W.I., Ologbo, A.C., Aliagha, U.G. and Ali, K.N. (2014). Preliminary study impact of building information modelling use in Malaysia. In Product Lifecycle Management for a Global Market. Berlin: Springer Berlin Heidelberg, 51-62. http://dx.doi.org/10.1007/978-3-662-45937-9_6.

Fowler, F.J. (1993). Survey Research Methods. 2nd Ed. Newbury Park, CA: Sage Publications.

Goh, B.H. and Chu, Y.L. (2002). Developing national standards for the classification of construction information in Singapore. Proceedings: International Council for Research and Innovation in Building and Construction CIB w78 Conference. Aarhus School of Architecture, Denmark, 12-14 June.

Hair, J.F., Black, W.C., Babin, B.J. and Anderson, R.E. (2010). Multivariate Data Analysis. 7th Ed. Upper Saddle River, NJ: Pearson Prentice Hall. http://dx.doi.org/10.1016/j.jmva.2009.12.014.

Hair, J.F., Black, W.C., Babin, B.J., Anderson, R.E. and Tatham, R.L. (2006). Multivariate Data Analysis. 6th Ed. Upper Saddle River, NJ: Pearson Prentice Hall.

River, N.J.Hammer, M. (1990). Re-engineering work: Don't automate, obliterate. Harvard Business Review, July-August: 104-112.

Haron, A.T. (2013). Organisational readiness to implement building information modelling: A framework for design consultants in Malaysia. PhD diss. University of Salford Manchester.

Harris, M., Ani, A.I.C., Haron, A.T. and Husain, A.H. (2014). The way forward for building information modelling (BIM) for contractors in Malaysia. Malaysian Construction Research Journal, 15(2): 1-9.

Hinterhuber, H.H. (1995). Business process management: The European approach. Business Change and Re-Engineering, 2(4): 63-73.

Iguarán, A. (2010). A First Step to Implementation of BIM in State Contracts, FONADE as a Management Tool in Your Construction Project. Bogota, Colombia: Uniandes.

Ismail, M.H. (2014). Building information modelling: A paradigm shift in Malaysian construction industry. BinaTECH, 2: 34-37.

126/PENERBIT UNIVERSITI SAINS MALAYSIA 
Jaafar, M., Ramayah, T., Abdul-Aziz, A.R. and Saad, B. (2007). Technology readiness among managers of Malaysian construction firms. Engineering Construction and Architectural Management, 14(2): 180-191. http://dx.doi.org/10.1 108/09699980710731290.

Jacobsson, M. and Linderoth, H.C.J. (2012). User perceptions of ICT impacts in Swedish construction companies: "It's not, just as it is". Construction Management and Economics, 30(5): 339-57. https://doi.org/10.1080/ 01446193.2012 .672757 .

Jayasena, H.S. and Weddikkara, C. (2013). Assessing the BIM maturity in a BIM infant industry. Proceedings of the Second World Construction Symposium 2013: Socio-Economic Sustainability in Construction. Colombo, Sri Lanka, 1415 June.

Kennedy, C. (1994). Re-engineering: The human costs and benefits. Long Range Planning, 27(5): 64-72. https://doi.org/10.1016/0024-6301 (94)90228-3.

Klenke, K. (1994). Information technologies as drivers of emergent organisational forms: A leadership perspective. In R. Baskerville, S. Smithson, O. Ngwenyama and J. DeGross (eds.). Transforming Organizations with Information Technology. Amsterdam: Elsevier Science, 323-341.

Koskela, L. and Salagnac, J. (1990). Determinants of the development of computer integrated construction. Paper presented at the 7th International Symposium on Automation and Robotics in Construction. Bristol, UK, 5-7 June.

Li, H., Irani, Z. and Love, P.E.D. (2000). The IT performance evaluation in the construction industry. Proceedings of the 33rd Hawaii International Conference on System Sciences. Piscataway, NJ: Institute of Electrical and Electronics Engineers (IEEE). http://dx.doi.org/10.1 109/HICSS.2000.926927.

Liang, Y. and Cohen, E. (1994). Business process re-engineering: An overview.Paper presented at the South-Central Small College Computing Conference. Amarillo, Texas, 15-16 April.

Liu, Z. (2010). Feasibility Analysis of BIM Based Information System for Facility Management at WPI. Worcester, Massachusetts: Worcester Polytechnic Institute.

Lowry, G. (2002). Modelling user acceptance of building management systems. Automation in Construction, 11(6): 695-705. https://doi.org/10.1016/S09265805(02)00010-9.

McCuen, T. and Suermann, P.E. (2007). The interactive capability maturity model and 2007 AIA TAP BIM award winners: Viewpoint \#33. AECbytes, 6 December. Available at: http://www.aecbytes.com/viewpoint/2007/ issue_33.html.

Miller, A., Radcliffe, D. and Isokangas, E. (2009). A perception-influence model for the management of technology implementation in construction. Construction Innovation, 9(2): 168-183. https://doi.org/10.1108/147141709 10950812.

Mohd-Nor, M.F.I., Usman, I.M.S. and Mazlan-Tahir, M. (2009). How the professional practice and the architecture education in Malaysia is catching up with the development of CAD. European Journal of Social Sciences, 9(4): 677-683.

Mui, L.Y., Aziz, A.R.A., Ni, A.C., Yee, W.C. and Lay, W.S. (2002). A survey of internet usage in the Malaysian construction industry. Journal of Information Technology in Construction, 7: 259-269. 
Ofori, G. and Toor, S. (2012). Leadership and construction industry development in developing countries. Journal of Construction in Developing Countries, 17(Supp. 1): 1-21.

Owen, R., Amor, R., Palmer, M., Dickinson, J., Tatum, C.B., Kazi, A.S. and East, B. (2010). Challenges for integrated design and delivery solutions. Architectural Engineering and Design Management, 6: 232-240. http://dx.doi.org/ 10.3763/aedm.2010.IDDS1.

Paschke, J. (2009). Adaptive IT capability and its impact on the competitiveness of firms: A dynamic capability perspective. PhD diss. RMIT University.

Peansupap, V. and Walker, D.H.T. (2006). Innovation diffusion at the implementation stage of a construction project: A case study of information communication technology. Construction Management and Economics, 24(3): 321-332. https://doi.org/10.1080/01446190500435317.

Peansupap, V. and Walker, D.H.T. (2005). Factors enabling information and communication technology diffusion and actual implementation on construction organisations. Journal of Information Technology in Construction, 10: 193-218.

Rezgui, Y. and Zarli, A. (2006). Paving the way to the vision of digital construction: A strategic roadmap. Journal of Construction Engineering and Management, 132(7): 767-776. http://dx.doi.org/10.1061/(ASCE)0733-9364(2006) 132:7(767).

Rogers, J., Chong, H.Y. and Preece, C. (2015). Adoption of building information modelling technology (BIM) perspectives from Malaysian engineering consulting services firms. Engineering, Construction and Architectural Management, 22(4): 424-445. http://dx.doi.org/10.1 108/ECAM-05-2014-0067.

Rosenberg, T.L. (2006). Building Information Modeling. Akron, OH: Roetzel and Andress. Available at: http://www.ralaw.com/resources/documents/ Building\%20Information \%20Modeling\%20-\%20Rosenberg.pdf.

Samuelson, O. (2011). Adoption processes for EDM, EDI and BIM in the Swedish construction industry. Paper presented at the CIB W78-W102 2011 International Conference. Sophia Antipolis, France, 26-28 October.

Sánchez, C. and Valencia, J. (2011). Design Organizational Process Maps for Implementation of BIM in a Construction Company. Bogota, Colombia: Uniandes.

Sarshar, M., Christiansson, P. and Winter, J. (2004). Towards virtual prototyping in the construction industry: The case study of the DIVERCITY project. In P. Brondon, H. Li, N. Shaffii and Q. Shen (eds.). Designing, Managing and Supporting Construction Projects through Innovation and IT Solutions: Proceedings of the World IT for Design and Construction (INCITE) Conference. Kuala Lumpur: Construction Industry Development Board (CIDB) Malaysia, 581-588.

Schnitt, D.L. (1993). Reengineering the organisation using information technology. Journal of Systems Management, 44(1): 14-21.

Smith, D. and Edgar, A. (2008). Building Information Modeling. Washington DC: National Institute of Building Sciences. Available at: http://www.wbdg. org/bim/bim.php [Accessed on 12 August 2010].

Someya, S. (1992). The role of R\&D in construction firms. MSc diss. Massachusetts Institute of Technology.

Sommerville, J. and Craig, N. (2006). Implementing IT in Construction. London and New York: Taylor and Francis.

128/PENERBIT UNIVERSITI SAINS MALAYSIA 
Son, H., Lee, S., Hwang, N. and Kim, C. (2014). The adoption of building information modeling in the design organization: An empirical study of architects in Korean design firms. Proceedings of the 31st International Symposium on Automation and Robotics in Construction and Mining (ISARC 2014). Sydney, Australia: International Association for Automation and Robotics in Construction (IAARC), 194-201.

Son, H., Park, Y., Kim, C. and Chou, J.S. (2012). Toward an understanding of construction professionals' acceptance of mobile computing devices in South Korea: An extension of the technology acceptance model. Automation in Construction, 28: 82-90. https://doi.org/10.1016/j.autcon. 2012.07.002.

Standards and Industrial Research Institute of Malaysia (SIRIM). (2009). Corporate Profile. Kuala Lumpur: SIRIM.

Tapscott, D. and Caston, A. (1993). Paradigm Shift: The New Promise of Information Technology. New York: McGraw-Hill.

Towers, S. (1996). Re-engineering: Middle managers are the key asset. Management Services, 40(12): 17-18.

Vroom, V.H. and Jago, A.G. (2007). The role of situation in leadership. American Psychologist, 62(1): 17-24. http://dx.doi.org/10.1037/0003-066X.62.1.17.

Willcocks, L. and Smith, G. (1994). IT-Enabled Business Process Re-Engineering: From Theory to Practice. Oxford: Oxford Institute of Information Management.

$\mathrm{XU}, \mathrm{H}$., Feng, J. and Li, S. (2014). Users-orientated evaluation of building information model in the Chinese construction industry. Automation in Construction, 39: 32-46. https://doi.org/10.1016/j.autcon.2013.12.004.

Yeomans, S.G., Bouchlaghem, N.M. and El-Hamalawi, A. (2006). An evaluation of current collaborative prototyping practices within the AEC industry. Automation in Construction, 15(2): 139-149. http://dx.doi.org/10.1016/ j.autcon.2005.02.011. 